\title{
A Global Catastrophic Biological Risk Is Not Just About Biology
}

\author{
Maurizio Barbeschi
}

G LOBAL CATASTROPHIC BIOLOGICAL RISK (GCBR) is a topic with relevance for many ongoing dialogues: What is national and international security? How can science itself be of harm or good? How do we advance global health security? What comprises One Health One Humanity? The Johns Hopkins Center for Health Security has started an important conversation. Of the many themes on which one could speak, one is underlined here: that a GCBR exists at the intersection of biology and (global) society.

In the case of the Black Death, one could argue that one pathogen was the ultimate killer, that a single factor eradicated many. But in defining the Black Death as a GCBR, is it only the exposure of the causative point that matters, or is there another set of conditions that need to be met? In the plague case, social elements, such as medieval societal, geopolitical, and anthropological conditions, were also at work: transportation routes, trade, religious beliefs, burial practices, the level of medicine, and so on.

In the case of the Texas Ebola index case, the Ebola was exactly the same virus we had in Sierra Leone. But in Texas, this initial single case triggered more panic because of the media reports and the situation where the patient was. With regard to a catastrophe, one must reflect on the single pathogen or causative agent as well as the social conditions that propagate it. To define a GCBR, one must consider the source, the pathogen and its features, the exposure, and epidemiology-but also the social context with its multiplying effect or its mitigation or boundary making.

Given the multifactorial nature of a biological (catastrophic) hazard, the interventions that would help stop a situation from evolving into a catastrophe would be event specific. What would the impact of the same Nigeria Ebola case be if it happened in Paris, New York, or Rio or New Delhi, where you have different health systems, different media approaches, different anthropological behavior, a different baseline of vaccination, and so on? The media in New York may say, "We have a problem, everybody stay at home," and people will follow it. If in other parts of the world, you say, "Stay at home," the answer may be, "Mmmm, they're possibly going to steal my car. Why would they say to stay home?!"

So, in addition to vaccines, hospitals, plans, and countermeasures, any intrinsic distrust between the majority of people and the government can be very influential in a biological event. In that case, if you want to send a message, you talk to the footballer and say, "Look, tell the people to stay home," and they may listen to him. Even if I try to give you a vaccine, nowadays will you take it? What is the root of such mistrust? As far as interventions to prevent a biological catastrophe, we need research regarding the vaccine, but also research regarding trust- the "social" elements, if you will.

This interplay between biology and society also means that GCBRs of the future may be different from those of the past or present. A classic mistake that is often made in science is that we take what we know and project it onto the future-the iconic "lamppost syndrome." We look for the lost keys under the lamppost because there is a light, not because we lost them there. We know a well-described incident or biological event, and we decide to avoid its occurrence in the future; ergo, we prepare for the thing that we know. What hits us next more often is not the old thing, but a new one.

From the biology perspective, the pure pathogen/hazard aspect, the only thing it may take for GCBRs is an alien bug coming in an asteroid or something totally novel that we as a species have never been exposed to, and we have the next extinction. From the society perspective, if something in one country becomes exported to another and it intersects with major points of geopolitical contention, then there could be cascading effects. Imagine a catastrophic dialogue

(C) Maurizio Barbeschi, 2017; Published by Mary Ann Liebert, Inc. This Open Access article is distributed under the terms of the Creative Commons Attribution Noncommercial License (http://creativecommons.org/licenses/by-nc/4.0/) which permits any noncommercial use, distribution, and reproduction in any medium, provided the original author(s) and the source are credited. 
about GCBRs in the north/south debate or an "otherreligion versus us" crusade or within two-enemies-block or rogue state tension - what kind of catastrophe could unfold because of these elements?

In thinking about GCBRs, we need to understand how a catastrophe could arise at the intersection of biological and social systems.

Maurizio Barbeschi

Scientist

World Health Organization Geneva, Switzerland

Email: barbeschim@who.int 